\title{
Elda Di Malio
}

Fernando Torres Quiróz

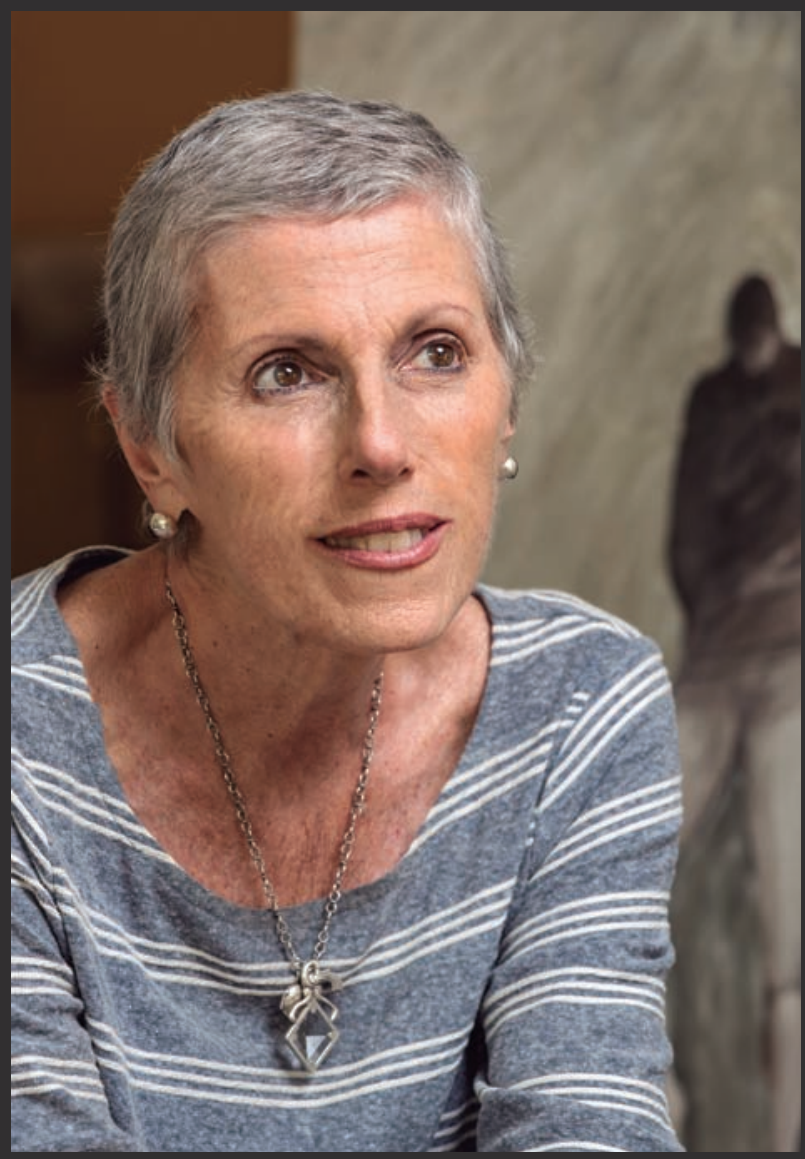

Pintar es

encerrarme en mí misma.

Es ir avanzando sola por un camino de luz $y$ de oscuridad, buscar respuestas sin preguntas concretas...

Elda Di Malio.

Foto: Daniel Giannoni. Archivo: Artes Visuales Icpna. 
Es así como Elda Di Malio definía su pasión por el arte y la creación. Su recorrido por aquel sendero de luz y oscuridad, sensiblemente representado en su obra, parecería contradecir la personalidad diáfana y carismática con que iluminó las vidas de quienes tuvimos la suerte de conocerla.

Por circunstancias impuestas por la guerra, Elda nació en Cristal City, Texas, en 1946. Ese mismo año llegó a Lima con sus padres, Donato Di Malio y Alicia Mazzini, para radicar definitivamente en Perú. Era la segunda de tres hermanas y desde pequeña demostró una excepcional inclinación por las artes. Terminados los estudios secundarios, en 1962 inicia su formación artística en la academia de Germán Suarez Vértiz. Luego continuará con su proceso de formación en la flamante academia del Museo de Arte de Lima, teniendo como maestros a Leslie Lee, Juan Acha y Mahia Biblos, entre otros.

En 1965 realiza su primer viaje a Europa. Después de recorrer toda la península italiana se instala en Perugia, donde ingresa a la Universidad Italiana para Extranjeros. Allí estudia la historia y la cultura italiana y, paralelamente, aprende cerámica en la academia Pietro Vanucci, estudios que culminarán en el Centro Piloto Artesanal de Miraflores con los profesores Bernasconi y Bustamante, llegando a obtener el primer premio de esa especialidad. En ese mismo período estudia pintura en la Asociación Artística y Cultural Jueves.

Es precisamente en Jueves donde conoce a su entonces profesor, Venancio Shinki. 1967 marcará un nuevo derrotero en la vida de Elda Di Malio, al iniciar un romance que duraría por el resto de la vida de ambos protagonistas. Venancio y Elda desafiaron todo tipo de convencionalismos para consolidar un hogar. Ambos mantuvieron su propia identidad artística y fueron una pareja ejemplar en términos de amor, entrega y sacrificio. Se puede decir que a partir de entonces resulta difícil hablar de uno de ellos sin mencionar al otro, pues sus vidas eran una urdimbre inquebrantable, como los sentimientos que las habían fusionado.

Elda realizó su primera muestra individual en noviembre de 1973, en la Galería Trapecio, después de haber participado ya en varias colectivas. Un año después, luego de su segunda individual en la Galería 9, retorna a Italia, y en Milán aprende las técnicas del aguafuerte y la aguatinta en el taller gráfico de Giorgio Upiglio. Siguiendo su inagotable curiosidad por nuevas formas de expresión artística, estudia fotografía con Fernando La Rosa en la Foto Galería Secuencia. Ese mismo año, 1976, se retira de la Aspap para formar el nuevo Sindicato Único de Trabajadores de la Artes Plásticas-Sutap.

Su vida profesional siguió su curso con más de 15 exposiciones individuales y múltiples colectivas. Visitó cuatro continentes exhibiendo su trabajo o realizando turismo cultural, lo que le permitió visitar las culturas ancestrales de Europa, Asia y África. Se involucró en proyectos vinculados a las artes visuales, colaborando en diferentes concursos y obras benéficas. Recibió reconocimientos y tuvo una muestra retrospectiva abarcando 35 años de su trayectoria en el Icpna.

Elda Di Malio plasmó en sus lienzos su íntima y visceral percepción del ser humano y sus ataduras a sus propias circunstancias. Sin concesiones ni aspavientos, nos enfrenta a nuestras propias limitaciones con imágenes producto de su aguda observación y capacidad de análisis. Elda tomaba fotografías de situaciones cotidianas para luego rescatar la metáfora visual que, convertida en discurso, genera la confrontación con realidades ineludibles y que aparentemente nos son ajenas. Mucho ha sido escrito y dicho por críticos y comentaristas expertos en el análisis de su propuesta artística. Sin embargo, habría que enfatizar que Elda ha sido una de las personas más coherentes que he tenido la fortuna de conocer y, por lo tanto, su obra es el reflejo de sí misma. 
En un medio a veces mezquino y siempre competitivo, la artista mantuvo su propio discurso más allá de modas y tendencias. Su vida transcurrió por la ruta que ella construyó con valor, coraje y optimismo. Sus últimos años estuvieron dedicados a velar por la salud de su compañero. Elda no tuvo tiempo de pensar en sí misma y siempre estuvo brindando atención a todos los amigos con su cálido sentido de la hospitalidad y fraternal alegría. La terraza de su hogar fue escenario de entrañables reuniones donde se conversaba de todo. Discusiones apasionadas sobre política, sobre las artes y también ocurrencias llenas de buen humor, constituyeron un espacio de cordialidad y confianza que jamás podremos olvidar.

Los últimos meses de su vida trabajó arduamente en la edición del libro que originalmente se circunscribía a la trayectoria de Venancio. Costó mucho convencerla para que aceptara la inclusión de la suya en el proyecto. Shinki-Di Malio fue publicado gracias al Icpna, veintitrés días antes de su partida. El proceso compartido con Luis Eduardo Wuffarden fue una permanente lección de fortaleza y compromiso. El registro exigía una selección de textos, fotografías y documentos acumulados a lo largo de varias décadas. Esta revisión llegó a ser agotadora y poco a poco su desgaste físico se ponía en evidencia. Sin embargo, nunca suspendió una reunión y, desafiando a su propia debilidad, siguió adelante de un modo ejemplar. Fue muy duro verla exigiéndose más allá del dolor, pero siempre atenta al mínimo detalle. A pesar de las circunstancias, fue un privilegio ser parte de un ejercicio tan íntimo e introspectivo, que nos permitió conocerla en una dimensión superlativa.

Ahora todo está en silencio y sus gatos deambulan por el salón y los jardines buscando el calor de su ama. Ha quedado un vacío tan grande que nada ni nadie podrá volver a llenar. En alguna ocasión me comentó que estaba segura de que Venancio la estaba esperando. Ahora sabemos todos que así ha sido. Finalmente, están juntos para seguir por la eternidad como ellos querían: caminando de la mano. A nosotros solamente nos resta iniciar el duro aprendizaje de seguir viviendo sin la presencia de dos personas que fueron indispensables en nuestras vidas. Solamente nos consuela la posibilidad del reencuentro con su cálido abrazo en el último horizonte. 